\title{
Mengenal Produk Perawatan Rambut yang Baik
}

\author{
Nopi Rantika \\ Program Magister Farmasi, Fakultas Farmasi, Universitas Padjadjaran, Sumedang, 45363 \\ email: nopi17002@mail.unpad.ac.id
}

\section{Abstrak :}

Beberapa orang mengeluarkan uang untuk melakukan perawatan rambut. Banyak produk yang beredar dipasaran, dengan merek yang berbeda-beda. Terdapat beberapa bahan kimia di balik shampo dan conditioner rambut yang biasa digunakan, yang membuat rambut terlihat mengkilap dan indah. Rambut perlu $\mathrm{pH}$ agak asam (sekitar $\mathrm{pH} 4-5$ ). Pada $\mathrm{pH}$ ini ikatan non kovalen pada untai rambut akan terjaga. Sabun memiliki $\mathrm{pH}$ agak basa (kira-kira $\mathrm{pH} 8.5$ ), yang dapat menyebabkan beberapa interaksi non kovalen seperti ikatan disulfida, sehingga melemahkan rambut. Saat ini, mayoritas sampo menggunakan surfaktan yang tidak berasal dari sabun. Surfaktan yang digunakan saat ini adalah anionik (mis.bermuatan negatif), seperti natrium lauril sulfat. Hilangnya lapisan minyak pada rambut bisa membuat rambut telihat kusut, kusam dan terasa kering. Menggunakan kondisioner setelah keramas dapat melindungi ramut, rambut akan terlihat lebih lembut dan berkilau. Pembentuk busa adalah bahan surfaktan yang masing-masing berbeda daya pembuat busanya. Busa adalah emulsi udara dalam cairan. Bahan tambahan lainnya seperti pengental, pemisah logam, penyeimbang $\mathrm{pH}$, dan pewarna sering digunakan dalam produk perawatan rambut.

Keyword : rambut, shampo, surfaktan, sabun

\section{Pendahuluan}

Rambut terdiri dari tiga lapisan utama. Lapisan terluar adalah kutikula. Lapisan kutikula merupakan struktur yang menutupi permukaan rambut, melindungi untai rambut serta memberikan sifat estetika tertentu, seperti bersinar. Korteks yang terletak di bawah lapisan kutikula dan berisi pigmen yang memberikan warna rambut. Lapisan yang melintang di bagian tengah untai rambut ini dikenal sebagai medula. Ketiga lapisan itu terdiri dari sel-sel mati yang kaya protein.

Rambut baru muncul dari folikel rambut, yaitu di dekat kulit kepala yang memiliki keterpaparan yang jauh lebih sedikit terhadap sumber kerusakan fisik atau kimiawi, seperti panas dari pengeringan rambut atau pewarna rambut. Proses ini dapat merusak dan melemahkan lapisan kutikula, menurunkan kualitas rambut dari ujung ke ujung. Rambut dilapisi oleh minyak yang disekresikan oleh kelenjar di dekat folikel rambut. Ini memberi tingkat perlindungan pada permukaan kutikula.

Lapisan minyak ini dapat menyerap minyak apa pun dan paparan kotoran , serta senyawa yang terkandung dalam produk styling. Ini berarti rambut kita perlu dicuci agar tetap terasa nyaman dan terlihat bersih. Lapisan minyak tidak bisa dibilas dengan air karena sifatnya yang hidrofobik, jadi shampo digunakan untuk membantu membersihkan rambut anda. 


\section{Sabun dan surfaktan}

Istilah 'sampo' diyakini berasal dari penjajahan India, ketika melakukan pijat kepala, seringkali mereka menggunakan minyak. Pada abad kesembilan belas, muncul pemakaian sabun untuk membersihkan rambut.

Agen pembersih seperti sabun dan deterjen mampu membuat zat berminyak lebih larut dalam air dengan mengurangi tegangan permukaan antara keduanya.

Sabun dan deterjen mengandung sejenis molekul yang diketahui sebagai surfaktan. Molekul surfaktan mengandung dua bagian yaitu kelompok kepala polar yang bersifat hidrofilik dan kelompok ekor non-polar bersifat hidrofobik.

Kelompok kepala polar tertarik ke kutub molekul lain, seperti air, dan ditolak oleh molekul nonpolar seperti minyak. Sebaliknya, ekor non-polar tertarik pada minyak dan ditolak oleh molekul polar. Molekul surfaktan akan memposisikan dirinya pada antarmuka antara minyak dan air.

\section{Sampo bukan sabun}

Sabun tidak cocok untuk mencuci rambut. Mereka bisa menyebabkan iritasi kulit kepala dan dapat mengakibatkan lapisan tipis pada rambut, serta membuat rambut tampak kusam.

Rambut perlu $\mathrm{pH}$ agak asam (sekitar $\mathrm{pH}$ 4-5). Pada $\mathrm{pH}$ ini ikatan non kovalen pada untai rambut akan terjaga. Sabun memiliki $\mathrm{pH}$ agak basa (kira-kira $\mathrm{pH}$ 8.5), yang dapat menyebabkan beberapa interaksi non kovalen seperti ikatan disulfida, sehingga melemahkan rambut.

Penggunaan sabun secara terus-menerus pada rambut menurunkan jumlah interaksi non kovalen, sehingga meningkatkan jumlah kerusakan rambut. Saat ini, mayoritas sampo menggunakan surfaktan yang tidak berasal dari sabun. Surfaktan yang digunakan saat ini adalah anionik (mis.bermuatan negatif), seperti natrium lauril sulfat.

Surfaktan anionik cenderung menghasilkan sejumlah besar busa dan busa ini dapat mengangkat kotoran dan minyak dari rambut ketika dibilas.Tindakan pembersihan dengan menggunakan sampo juga menghilangkan lapisan pelindung minyak yang mengelilingi rambut.

Dengan demikian, beberapa sampo mengandung zat yang mampu memproteksi lapisan minyak rambut atau disebbut dengan conditioners.

\section{Pelembut (Conditioners)}

Hilangnya lapisan minyak pada rambut bisa membuat rambut telihat kusut, kusam dan terasa kering. Menggunakan kondisioner setelah keramas dapat melindungi ramut, rambut akan terlihat lebih lembut dan berkilau.

Lapisan ini membantu mengisi area permukaan rambut yang rusak serta membuat untai rambut menjadi lebih halus. Ada beberapa agen yang bisa digunakan, termasuk silikon dan surfaktan kationik (yaitu bermuatan positif). 


\section{Surfaktan kationik}

Surfaktan kationik, diantaranya mengandung amina kuartener, dimana gugus ini mampu melapisi rambut, muatan positifnya tertarik pada permukaan elektronegatif untai rambut. Surfaktan kationik ini juga membantu mengurangi penumpukan listrik statis di antara helai rambut.

\section{Silikon}

Senyawa yang mengandung silikon mengandung atom oksigen. Mereka efektif dalam menghaluskan helai rambut, sehingga rambut mudah disisir. Sifat silikon dapat diubah dengan memvariasikan kelompok kimia yang melekat pada atom silikon dan rantai panjangnya. Sebagai contoh, dimetikon, suatu polimer yang banyak digunakan sebagai kondisioner, memiliki dua kelompok metil yang terikat pada masing-masing atom silikon.

\section{Pembentuk busa}

Pembentuk busa adalah bahan surfaktan yang masing-masing berbeda daya pembuat busanya. Busa adalah emulsi udara dalam cairan.

Kemampuan membentuk busa tidak menggambarkan kemampuan membersihkan. Busa yang terbentuk akan segera terikat dengan lemak sebum sehingga rambut yang lebih bersih akan menimbulkan busa yang lebih banyak pada pengulangan pemakaian shampoo. Busa yang terbentuk lazim diberi penguat yang menstabilkan busa agar lebih lama terjadi.

\section{Bahan tambahan lain}

Pengental (thickener) dan pengeruh (opacifier)

Bahan ini ditambahkan untuk menyenangkan konsumen, keduanya tidak menggambarkan daya bersih dan konsentrasi bahan aktif dalam sampo. Zat pengental biasanya gom sintetik/alam : tragakan, gom akasia, hidroksietilselulosa.

\section{Pemisah logam}

Dibutuhkan keberadaannya untuk mengikat logam berat $(\mathrm{K}, \mathrm{Mg})$ yang terdapat dalam air pencuci rambut, misalnya etilen diamin tetra asetat (EDTA).

\section{$\mathrm{pH}$ balance}

Diperlukan agar menetralisasi reaksi basa yang terjadi dalam penyampoan rambut, misalnya asam sitrat.

\section{Pemberi warna dan bau}

Bahan ini ditambahkan untuk memberi kesan nyaman bagi konsumen yang memakai.

Pengawet : formaldehid, metilhidroksibenzoat, propilhidroksibenzoat, alkil anisol, butil hidroksi benzoat 
Jadi sekarang ketika mencuci rambut, farmasetikers akan tahu mengapa rambut terasa berbeda setelah keramas dibanding dengan sebelumnya.

Sekarang farmasetikers memiliki pemahaman yang lebih baik terhadap produk perawatan rambut, baca label pada botol kemudian lihat bahan-bahan yang terkandung dalam produk perawatan rambutnya.

\section{DAFTAR PUSTAKA}

James B.M, R. et. al. (2016). Surfactants and Skin. Inform, 27 (1), 694-699.

Review, C. (n.d.). The chemistry of shampoo and conditioner.

Rhein, L. (2007). Handbook for Cleaning/Decontamination of Surfaces. Handbook for Cleaning/Decontamination of Surfaces, 305-V. https://doi.org/10.1016/B978-0444516640/50009-7

Walters, R. M., Mao, G., Gunn, E. T., \& Hornby, S. (2012). Cleansing formulations that respect skin barrier integrity. Dermatology Research and Practice, 2012. https://doi.org/10.1155/2012/495917 